\title{
Sipuncula of the Magellan area compared with adjacent regions of Antarctica*
}

\author{
J. I. SAIZ-SALINAS and S. PAGOLA-CARTE \\ Universidad del País Vasco, E-48080 Bilbao, Apdo. 644, Spain.
}

\begin{abstract}
SUMMARY: The Magellan sipunculan fauna includes 4 families, 7 genera and 16 species. A comparison between this fauna and that from adjacent regions of Antarctica has been made. A total of 8 species and 3 genera are shared by the compared areas. Univariate analyses show no significant statistical differences among the investigated faunas, whereas a multivariate analysis corroborates that the effects of the Antarctic Convergence are stronger at the level of genera than species. Only 3 genera were able to cross over this zoogeographical boundary. However, these 3 genera succeeded in the new biotopes of Antarctica, since a total of 16 species have been recorded, compared with the 8 species only found in the Magellan region.

Key words: Sipuncula, zoogeography, Magellan region, Antarctic Convergence.

RESUMEN: Sipuncula de la Región Magallánica comparada con zonas adyacentes de la ANTÁRtida. - La fauna magallánica de sipuncúlidos presenta 4 familias, 7 géneros y 16 especies. Se lleva a cabo una comparación entre esta fauna y la procedente de zonas adyacentes de la Antártida. Un total de 8 especies y 3 géneros están presentes en ambas zonas. Los resultados del análisis univariante indican la ausencia de diferencias estadísticas significativas entre las faunas investigadas, mientras que el análisis multivariante revela que los efectos de la Convergencia Antártica son más importantes a nivel de género que de especie. Sin embargo, estos géneros tuvieron cierto éxito en la colonización progresiva de los nuevos biotopos antárticos, dado que se han encontrado un total de 16 especies frente a las 8 exclusivas del área magallánica.
\end{abstract}

Palabras clave: Sipuncula, zoogeografía, región magallánica, Convergencia Antártica.

\section{INTRODUCTION}

The southernmost part of the American continent, the Magellan Province, has been postulated as an important portal of entry into the Antarctic for many marine invertebrate groups (Knox, 1994). Sipunculans are a small phylum of coelomate, protostomous and unsegmented worms, which show a worldwide distribution throughout all oceans. However, the greater proportion of species remains to be confined in shallow waters of tropical regions

\footnotetext{
*Accepted July 17, 1998
}

(Murina, 1984; Cutler 1994). Among the approximately 150 species belonging to this phylum (Cutler, 1994), we can observe a continuum from endemic to cosmopolitan species. As biochemical data are scarce, these kinds of zoogeographical considerations are based on morphological characters. Since a review of the sipunculans from Antarctica was recently achieved (Saiz Salinas, 1995), it is interesting, therefore, to investigate: (1) the affinities between the Magellan and Antarctic sipunculan faunas; and (2) the efficacy of the Antarctic Convergence as a zoogeographical barrier in the spatial distribution of sipunculans. 
a
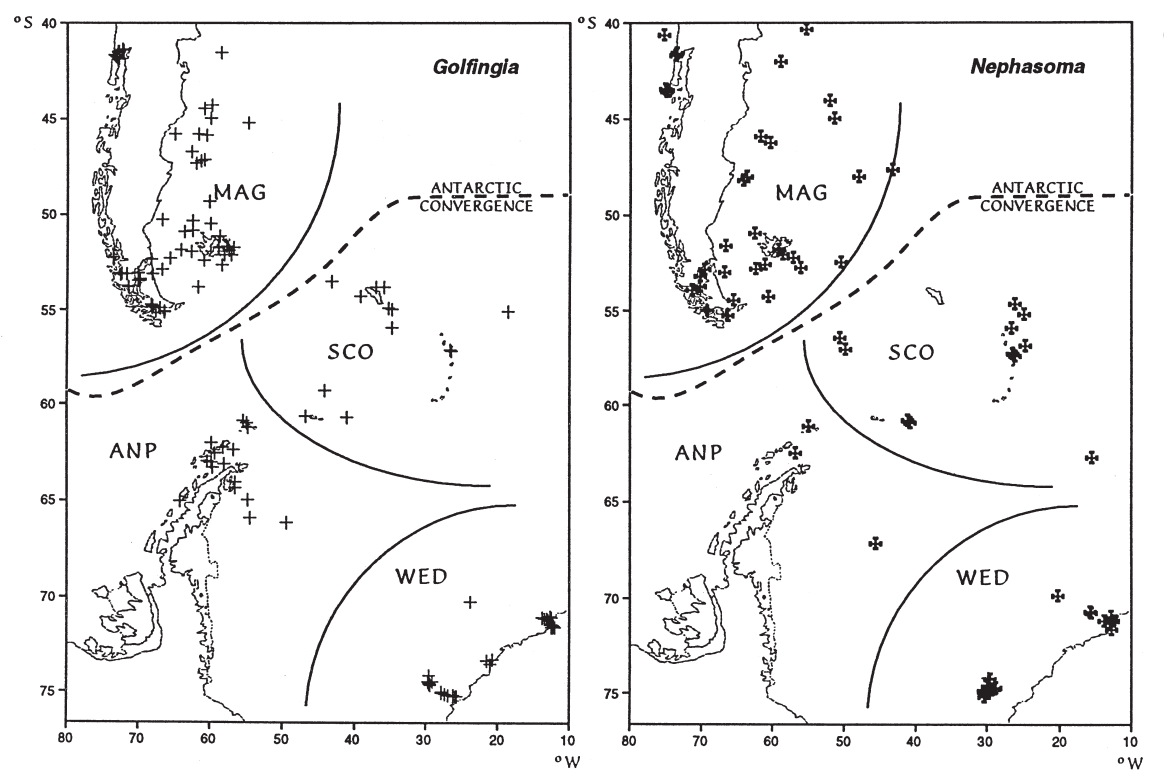

b

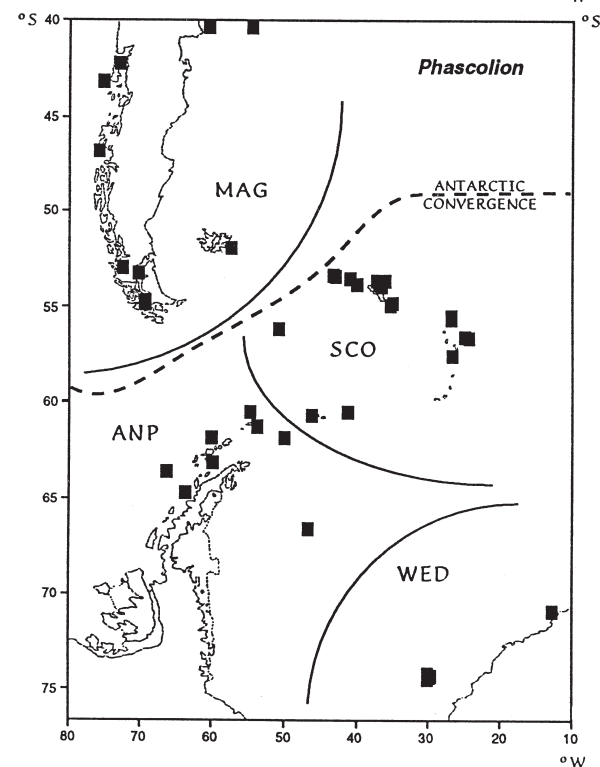

FIG. 1. - Distribution maps of Magellan and Antarctic sipunculans. All records of the genus Golfingia are shown in (a); genus Nephasoma in (b); genus Phascolion in (c); and remaining genera in (d). Abbreviations as in Table 1.

The credit for the first published description of a sipunculan from the Magellan area should perhaps go to the French naturalist Lesson (1830), who named Sipunculus lumbrisciformis from Soledad, the eastern Falkland Island. Baird (1868) reported Phascolosoma capsiforme from the same group of Islands. Next, the 'Lund University Chile Expedition 1948-1949' made important collections along the Chilean coast. The sipunculans were described by Wesenberg-Lund (1955). Later on, Tarifeño and Rojas (1978) published a comprehensive review of the Chilean sipunculans. Other reviews, which included part of this fauna, were previously done by Edmonds (1969) and Amor (1975) among others.
Recently, the Chilean-German-Italian Magellan "Victor-Hensen" Campaign in 1994 (Arntz and Gorny, 1996) made extensive collections, the sipunculans being studied by us (unpublished report).

\section{MATERIAL AND METHODS}

\section{Study area}

The investigated area (Fig. 1) was divided in 2 or 4 units depending on the following comparisons: (1) Magellan (MAG) sipunculan fauna vs. fauna from adjacent regions of Antarctica (ANT) pooled togeth- 
er; (2) Magellan (MAG) sipunculans when simultaneously compared with the fauna from neighbouring Antarctic areas, such as the Scotia (SCO) Arc Islands, Antarctic Peninsula (ANP) and Weddell Sea (WED). The Magellan area is a vast zoogeographical zone not well delimited in its septentrional margin (see Briggs, 1974). Previous South American authors defined this marine area as the Pacific coast south of Chiloé $\left(42^{\circ} \mathrm{S}\right)$ and the Atlantic coast south of Bahía Blanca in Argentina (40 $\mathrm{S}$ ) (Stuardo, 1964 in Tarifeño and Rojas, 1978; Amor, 1975). For convenience we have included all the sipunculan records south of latitude $40^{\circ} \mathrm{S}$ up to the border of the Antarctic Convergence.

\section{Statistical analyses}

The numbers of records of each species in every area were compiled from the scientific literature, based mainly on the work of Stephen and Edmonds (1972), Cutler (1994) and Saiz Salinas (1995). Thus, a data matrix with species in rows and geographical areas in columns was constructed (Table 1). Later, species data were standardized using percentages, to avoid the bias for different sampling efforts in the different investigated areas.

To investigate for differences between the MAG sipunculans when compared with ANT (adjacent regions of Antarctica pooled together), we used a non-parametric statistical test such as Wilcoxon W test, since the data were not normally distributed. By contrast, a simultaneous comparison among the sipunculan faunas from MAG, SCO, ANP and WED was tested by using a non-parametric statistical Kruskal-Wallis analysis. Additionally, we have used multivariate analysis to quantify differences / affinities among the 4 investigated areas. Dendrograms and MDS (Multidimensional scaling) plots were performed on matrices of association between all pairs of investigated areas computed using the BrayCurtis measure. Separate analyses were performed at each of the two taxonomic levels (species, genera) with percentage abundance data and also binary (presence/absence) data. This allowed comparison of results from different weightings of rare and common taxa. Univariate analyses were performed using SPSS statistical software and multivariate analyses using the PRIMER package. Statistical significance was always assessed at a probability level of 0.05 .

\section{RESULTS}

The Magellan sipunculan fauna was found to contain 16 species arranged in 7 genera and 4 families. Table 1 lists the number of records of all species in the different areas under investigation. Where reasonable doubts exist concerning localities or rare

TABLE 1. - Record numbers of sipunculans in the Magellan and neighbouring areas of Antarctica. Abbreviations: MAG = Magellan area; $\mathrm{ANP}=$ Antarctic Peninsula; $\mathrm{SCO}=$ Scotia Arc islands $;$ WED $=$ Weddell Sea .

\begin{tabular}{|c|c|c|c|c|}
\hline Species & MAG & $\mathrm{SCO}$ & ANP & WED \\
\hline Golfingia (G.) anderssoni (Théel, 1911) & 2 & 8 & 3 & 13 \\
\hline Golfingia (G.) elongata (Keferstein, 1862) & 0 & 0 & 1 & 0 \\
\hline Golfingia (G.) margaritacea (Sars, 1851) & 85 & 35 & 22 & 66 \\
\hline Golfingia (G.) muricaudata (Southern, 1913) & 0 & 1 & 1 & 3 \\
\hline Golfingia (G.) vulgaris (de Blainville, 1827) & 0 & 1 & 0 & 0 \\
\hline Nephasoma (N.) abyssorum (Koren and Danielssen, 1875) & 0 & 0 & 0 & 6 \\
\hline Nephasoma (N.) capilleforme (Murina, 1973) & 2 & 1 & 0 & 0 \\
\hline Nephasoma (N.) confusum (Sluiter, 1902) & 0 & 0 & 1 & 1 \\
\hline Nephasoma (N.) cutleri (Murina, 1975) & 0 & 1 & 0 & 1 \\
\hline Nephasoma (N.) diaphanes (Gerould, 1913) & 52 & 14 & 1 & 13 \\
\hline Nephasoma (N.) eremita (Sars, 1851) & 4 & 0 & 2 & 1 \\
\hline Nephasoma (N.) pellucidum (Keferstein, 1865) & 2 & 0 & 0 & 0 \\
\hline Onchnesoma steenstrupii Koren and Danielssen, 1875 & 1 & 0 & 0 & 0 \\
\hline Phascolion (Isomya) convestitum (Sluiter, 1902) & 0 & 0 & 0 & 6 \\
\hline Phascolion (I.) hedraeum Selenka and de Man, 1883 & 2 & 0 & 1 & 0 \\
\hline Phascolion (Montuga) lutense Selenka, 1885 & 0 & 5 & 1 & 0 \\
\hline Phascolion (M.) pacificum Murina, 1957 & 1 & 1 & 0 & 0 \\
\hline Phascolion (P.) strombus (Montagu, 1804) & 9 & 13 & 5 & 0 \\
\hline Phascolosoma (Fisherana) capitatum (Gerould, 1913) & 1 & 0 & 0 & 0 \\
\hline Themiste (T.) alutacea (Grube, 1858) & 2 & 0 & 0 & 0 \\
\hline Themiste (Lagenopsis) dehamata (Kesteven, 1903) & 1 & 0 & 0 & 0 \\
\hline Themiste (L.) lageniformis (Baird, 1868) & 1 & 0 & 0 & 0 \\
\hline Themiste (L.) minor (Ikeda, 1904) & 1 & 0 & 0 & 0 \\
\hline Thysanocardia catharinae (Grube, 1868) & 1 & 0 & 0 & 0 \\
\hline
\end{tabular}


identifications of specimens, the records were omitted. From the 16 species and 7 genera compiled for the Magellan area, only $8(50 \%)$ species and 3 $(42 \%)$ genera are shared with neighboring regions of Antarctica, which contains 8 different species not found in the Magellan area.

\section{Punta Arenas (Chile) vs. Puntarenas (Costa Rica)}

There are two geographical localities, "Punta Arenas" (Chile) and "Puntarenas" (Costa Rica), which were confused many times in the scientific literature. This questions the presence of a few but important species, such as:

Antillesoma antillarum (Grube,1858) which was recorded for Punta Arenas (seems to be Chile) by Hérubel (1908). Tarifeño and Rojas (1978) hesitated as to whether the original record of Grube (1858) was Chilean indeed; however, the title of Grube's article suggests Costa Rica. In fact, the species is mostly tropical and subtropical (Cutler, 1994).

Phascolosoma agassizii (Keferstein, 1866) and P. nigrescens (Keferstein, 1865) recorded for Punta Arenas (seems to be Chile) by Hérubel (1908). The

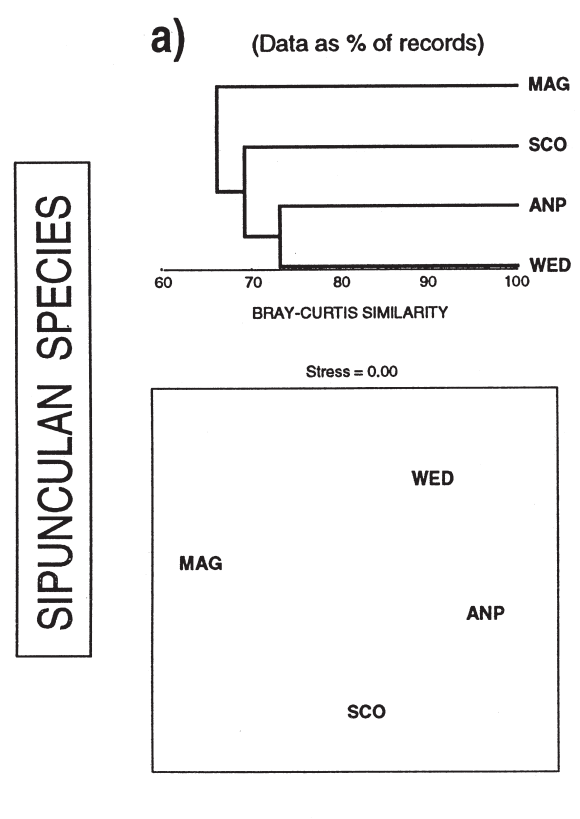

b) (Data as presence/absence)
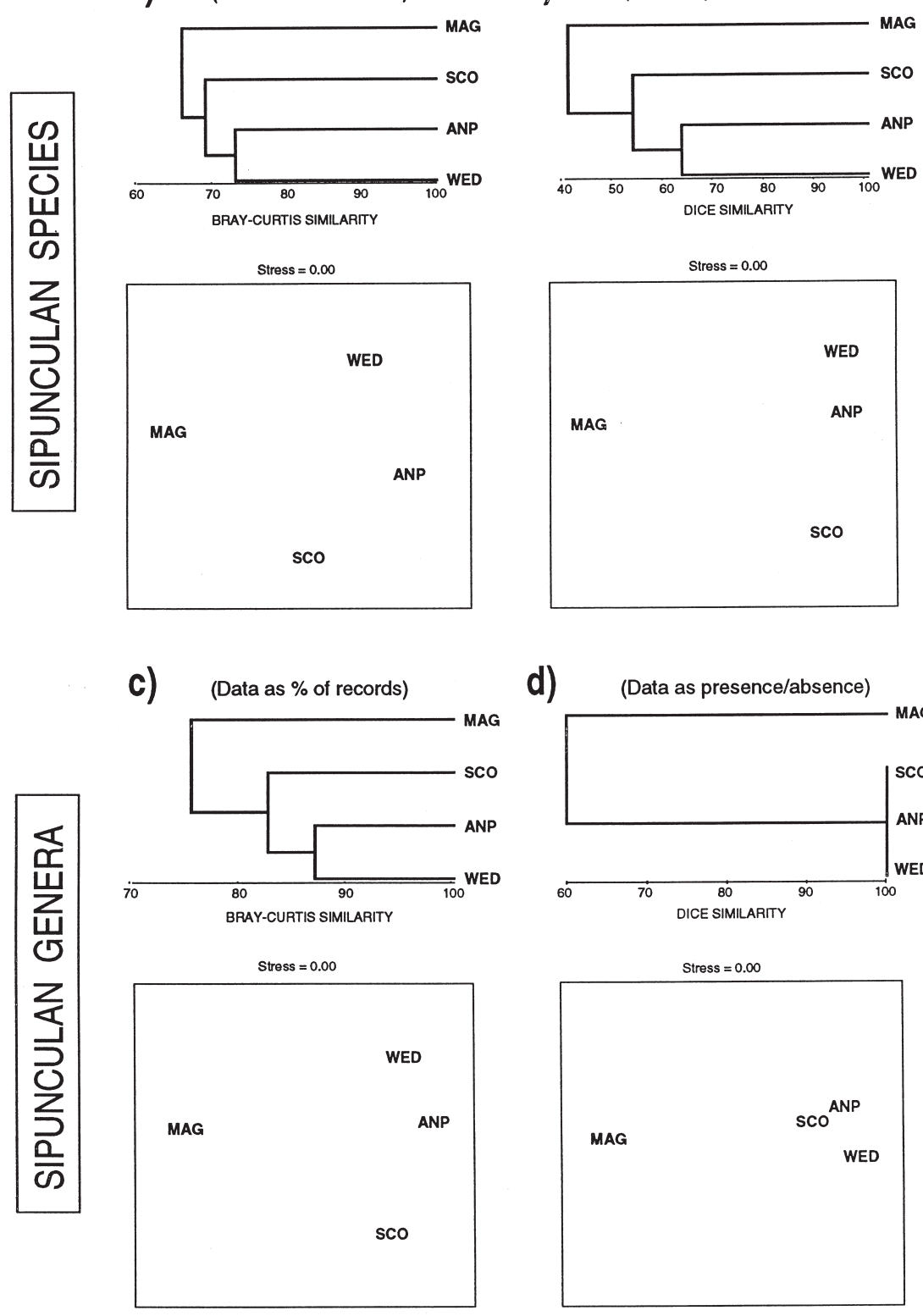

FIG. 2. - Dendrograms and MDS ordinations of the investigated areas using record numbers as percentages and binary data at the level both of species and genera. Abbreviations as in Table 1. 
first species has been recorded in South Africa and reaches Alaska; however the second is mostly circumtropical.

Sipunculus nudus Linnaeus, 1766 and S. phalloides (Pallas, 1774). Whereas the Chilean record of the first species was questioned by Tarifeño and Rojas (1978), the second was recorded by Leroy (1936) for Punta Arenas (seems to be Chile). The monograph of Cutler (1994) includes a temperate distribution for the first species; however the second is more tropical.

No doubt, it is urgent to confirm the presence or absence of all these above mentioned species with extensive identifications of further collections, mainly around the Punta Arenas (Chile) area.

\section{Univariate analyses}

There were no significant statistical differences between MAG vs. ANT areas after using W test with species data stated in percentage. When simultaneously compared the sipunculan faunas from MAG, SCO, ANP and WED areas using the K-W test, significant statistical differences were not found either. This suggests the existence of strong affinities among the compared faunas and minimal effects of the Antarctic Convergence zoogeographical barrier in the latitudinal distribution of these species of sipunculans.

\section{Multivariate analyses}

The results of the multivariate analyses are depicted in Figure 2 (a-d). A strong affinity among the four investigated areas is readily apparent in Figure $2 \mathrm{a}$ when record numbers (as percentages) were used for all species. In this case, the abundances of 3 species, Golfingia margaritacea, Nephasoma diaphanes and Phascolion strombus were so strong that contributions of rare species remained almost negligible. When species data were transformed as presence/absence, the effects of rare species are emphasized. Tenuous differences were shown in Figure 2b, with MAG relatively more separated from the rest, a circumstance which points to some effect of the Antarctic Convergence in the latitudinal distribution of sipunculans.

Aggregating species into genera, the undesirable effects of erroneous identifications are avoided. Almost the same result is achieved (Fig. 2c), with a gain of overall similarity among investigated areas. Finally, if we transform the abundances of genera into binary data (stated as presence or absence), the 3 Antarctic areas were clustered together (Fig. 2d), suggesting that the effects of the Antarctic Convergence barrier are at this stage readily apparent.

\section{DISCUSSION}

Although there are still important gaps in the knowledge of the geographical distribution of sipunculans, the results of the statistical analyses suggest the existence of strong faunal affinities among the four investigated areas. From here it can be inferred that a relevant sipunculan migration occurred through the islands of the Scotia Ridge from the Magellan area to the Antarctic continent. The Antarctic Convergence zoogeographical barrier was only effective in limiting the latitudinal distribution of four sipunculan genera (Fig. 2d), some of them very rare in the Magellan area. The other 3 genera (Fig. 2a-c), which were able to cross this zoogeographical boundary, succeeded in the new biotopes of Antarctica, since a total of 16 species in these 3 genera were recorded compared with the only 9 found in the Magellan area.

The degree of endemism in several groups of marine invertebrates has been used as a measure of faunal isolation (Gallardo, 1987) since the inception of the Antarctic Convergence. No endemisms are shown by Magellan and Antarctic sipunculans. In contrast many of the most abundant species are cosmopolitan such as Golfingia margaritacea, Nephasoma diaphanes and Phascolion strombus. This reflects either a fauna in stasigenesis with little change over extended periods of time, or a young fauna without enough time for further speciation. Moreover, the species differences between the two involved faunas can also be explained by deep-water migrations from the surrounding bathyal and abyssal plains around Antarctica. This mechanism has been found valid for some species of echiurans (Saiz Salinas, 1996).

As stated in Saiz Salinas (1995) the main feature concerning the distribution of sipunculans in the investigated areas is a progressive loss of genera and species along a polar gradient from locations above the Antarctic Convergence to the high latitudinal Antarctic regions. While unobserved factors may be of importance in the explanation of this loss of biodiversity, the effects of extremely cold temperatures appear as the main structuring factor. In conclusion, the Antarctic sipunculan 
fauna can be characterized as a depauperate outlying element of the far Southern hemisphere fauna.

\section{ACKNOWLEDGEMENTS}

This work was carried out under contract no. ANT 95-1011 of the Spanish CICYT (= Council of Scientific and Technical Research). S. Pagola-Carte received a post-graduate grant from the Basque Government during the period of the investigation.

\section{REFERENCES}

Amor, A. 1975. - Notas sobre Sipuncula de la Argentina, Brasil y Perú. Physis, Secc. A., 34 (88): 113-120.

Arntz, W. and M. Gorny. - 1996. Cruise report of the Joint ChileanGerman-Italian Magellan "Victor Hensen" Campaign in 1994. Ber. Polarforsch., 190: 1-113.

Baird, W. - 1868. Monograph of the species of worms belonging to the subclass Gephyrea; with a notice of such species as are contained in the collection of the British Museum. Proc. Zool. Soc. London, 1868: 76-114.

Briggs, J.C. - 1974. Marine Zoogeography. McGraw-Hill, New York.

Cutler, E.B. - 1994. The Sipuncula: their Systematics, Biology, and Evolution. Cornell University Press, New York.
Edmonds, S.J. - 1969. Sipuncula and Echiura. Antarct. Map Folio Ser., 11: 23-24.

Gallardo, V.A. - 1987. The sublittoral macrofaunal benthos of the Antarctic shelf. Environm Internat., 13: 71-81.

Grube, E. - 1858. Annulata Örstediana, Enumeratio Annulatorum, quae in itinere per Indian occidentalem et American centralen annis 1845-1848 suspecto legit cl. A.S. Örsted, adjectis speciebus nonnullis a cl. H. Kröyero in itinere ad American meridionalem collectis. Vidensk. Medd. Dansk naturhist. kjfbenhavn, 1858: 105-120.

Hérubel, M.A. - 1908. Expédition Antarctique Française (19031905) commandée par le Dr. Jean Charcot. Gephyriens. Documents Scientifiques. Paris: Maison et Cie, 8: 1-8.

Knox, G.A. - 1994. The Biology of the Southern Ocean. Cambridge University Press, Cambridge.

Leroy, P. - 1936. Les Sipunculiens du Muséum National d'Histoire Naturelle de Paris. Bull. Mus. nat. Hist. natur., 2ème sér., 8(5): 423-426.

Lesson, R.P. - 1830. Centurie Zoologique, ou choix d'animaux rares, nouveaux ou imparfaitementn connus; enrichi de planches inédites, dessinées d'après nature par M. Prêtre, gravées et coloriées avec le plus grand soin. G. Levrault, Paris.

Murina G.-V.V. - 1984. Ecology of Sipuncula. Mar. Ecol. Prog. Ser., 17: 1-7.

Saiz Salinas, J.I. - 1995. Sipuncula of the southeastern Weddell Sea (Antarctica). Polar Biol., 15: 307-317.

Saiz Salinas, J.I. - 1996. Echiura from South Shetland Islands together with a review of its geographic distribution in the Antarctic Ocean. Polar Biol., 16: 363-370.

Stephen, A.C. and S.J. Edmonds.. - 1972. The Phyla Sipuncula and Echiura. Trustees of the British Museum Natural History, London.

Tarifeño, E. and M. Rojas. - 1978. El phylum Sipuncula en Chile. Stud. Neotrop. Fauna Environm.: Ecol. Syst., 13: 93-134.

Wesenberg-Lund, E. - 1955. Reports of the Lund University Chile Expedition 1948-1949. 19. Gephyrea from Chile. Lunds Univ. Årssk. N.F. Avd. 2, 51(10): 1-24. 